\title{
DNA Microarray Probe Preparation by Gel Isolation Nested PCR
}

\author{
Hong-min Wang, Wen-li Ma*, Hai Huang, Wei-wei Xiao, Yan Wang and Wen-ling Zheng ${ }^{\dagger}$ \\ Institute of Molecular Biology, First Uniform Medical University, Guangzhou 510515 \\ Institute of Molecular Oncology, Liu Hua Qiao Hospital, 510010, P. R. China
}

Received 10 July 2003, Accepted 22 September 2003

\begin{abstract}
To develop a simplified method that can rapidly prepare DNA microarray probes in a massive scale, a lambda phage genomic DNA-fragments library was constructed for the microarray-probes collection. Four methods of DNA band recovery from the first PCR products were tested and compared. The DNA microarray probes were collected by a novel method of nested PCR that was mediated by gel isolation of the first PCR products. This method was named GIN-PCR. The probes that were prepared by this GIN-PCR technique were used as subjects to fabricate a DNA microarray. The results showed that a wooden toothpick was superior to the other 3 methods, since this technique can steadily transfer the DNA bands as the template of the second PCR after the first PCR. A group of probes were successfully collected and DNA microarrays were constructed using these probes. Hybridization results demonstrated that this technique of DNA recovery and probe preparation was rapid, efficient, and effective. We developed a cost-effective and less labor-intensive method for DNA microarray probe preparation by nested PCR that is mediated by wooden toothpick transfer of the DNA bands in the gel after electrophoresis.
\end{abstract}

Keywords: DNA microarray, DNA recovery, Nested-PCR, Probe preparation

\section{Introduction}

DNA microarray is one of the emerging and leading biotechnologies in life science studies and applications (Smith et al., 2003). The probe preparation is a key step for microarray fabrication. There are a few methods of probe

\footnotetext{
*To whom correspondence should be addressed. Tel: 86-20-61648210, 36622203; Fax: 86-20-61647755, 36622203 E-mail: wenli@fimmu.edu.cn
}

preparation that have been reported. These include light directed in situ synthesis (Albert et al., 2003), oligo designing and synthesis (Wang et al., 2003), target fragments PCR (Dziejman et al., 2002), RT-PCR of mRNA from interested tissues for gene expression profile study (Schofield et al., 2002), etc., but massive probe preparation is still a hurdle for microarray manufacture. Here, we report an improved method of electrophoresis gel isolation nested PCR (GIN-PCR) for DNA microarray probe preparation from genomic DNA of lambda phage.

\section{Materials and methods}

Primer design The genome of lambda phage for prospective DNA microarray construction was digested by Sau3AI into fragments of hundred base pairs and cloned into a pMD18-T vector (TaKaRa, Shiga, Japan). Two pairs of nested PCR primers were designed beside the cloning site to amplify the inserted DNA fragment for microarray probe preparation. The primers were designed using Oligo 6.40 software.

Sau3AI digest of lambda phage DNA One $\mu \mathrm{g}$ Lambda phage DNA (Bacteriophage $\lambda$ cI857 Sam7, TaKaRa, Shiga, Japan) was digested in $20 \mu \mathrm{l}$ of a system containing an $\mathrm{H}$ Buffer by $5 \mathrm{U}$ of Sau3AI (TaKaRa) at $37^{\circ} \mathrm{C}$ for $3 \mathrm{~h}$. The reaction was stopped by a water bath at $70^{\circ} \mathrm{C}$ for $10 \mathrm{~min}$. The digested fragments were recovered by ethanol precipitation. After vacuum dry, the precipitate of lambda DNA fragments was resolved in $10 \mu \mathrm{l}$ of ultra pure water (UPW).

Add A-tail to the digested fragments In the $10 \mu$ solution of DNA fragments, $10 \mu \mathrm{l}$ of $2 \times$ premix containing Taq polymerase $0.08 \mathrm{U} / \mu \mathrm{l}$, dNTP $0.4 \mathrm{mM} / \mathrm{each}, 4 \mathrm{mM} \mathrm{MgCl}_{2}$, and $2 \times \mathrm{PCR}$ buffer was added, then incubated in a water bath at $72^{\circ} \mathrm{C}$ for $30 \mathrm{~min}$. After the Taq polymerase-catalyzed reaction, the sticky end of all of the digested fragments had an overhanging base "A", which can be used to ligate with " $T$ " at the end of the pMD18-T vector in the upcoming step. The products were purified by ethanol precipitation.

A-T cloning After vacuum dry, the precipitates of the lambda 
DNA fragments were resolved in $4 \mu \mathrm{l}$ of UPW, followed by adding $1 \mu \mathrm{l} \mathrm{pMD} 18$-T vector $(50 \mathrm{ng} / \mu \mathrm{l})$ and $5 \mu \mathrm{l}$ ligation solution I, then ligated at $16^{\circ} \mathrm{C}$ for $5 \mathrm{~h}$. For the control, another ligation reaction using $1 \mu \mathrm{l}$ of a $500 \mathrm{bp}$ control fragment was performed according to the protocols supplied in the kit (TaKaRa). After ligation, $5 \mu \mathrm{l}$ of the reaction solution was added to $100 \mu \mathrm{l}$ of freshly prepared competent cells of $E$. coli XL-1. After transformation, $100 \mu \mathrm{l}$ of the transformed E. coli XL-1 was plated on a $90 \mathrm{~mm}$ agar dish containing ampicillin (Amp), 5-bromo-4-chloro-3-indolyl- $\beta$-Dgalactoside (X-gal), and isopropyl- $\beta$-D-thiogalactoside (IPTG). The plate was incubated at $37^{\circ} \mathrm{C}$ for $15 \mathrm{~h}$. The white clones were picked for foreign lambda DNA fragments-insertion identification.

First PCR for identification The white clones were picked and transferred to a $1.5 \mathrm{ml} \mathrm{EP}$ tube containing $500 \mu \mathrm{LB}$ (with $100 \mu \mathrm{g}$ / $\mathrm{ml}$ Ampicillin), then incubated at $37^{\circ} \mathrm{C}$ for $5 \mathrm{~h}$. Next, $100 \mu \mathrm{l}$ of the bacteria solution were centrifuged and the resulting pellet was collected and re-suspended in $100 \mu \mathrm{l}$ of UPW, boiling for $10 \mathrm{~min}$. After centrifugation at $12,000 \mathrm{rpm}$ for $5 \mathrm{~min}$, the supernate was used as the PCR template. The $20 \mu \mathrm{l} \mathrm{PCR} \mathrm{reaction} \mathrm{system}$ contained $6 \mu \mathrm{l}$ UPW, $10 \mu \mathrm{l} 2 \times$ premix, $1 \mu \mathrm{l}$ primer F1 $(10 \mu \mathrm{M})$, $1 \mu \mathrm{l}$ primer F2 $(10 \mu \mathrm{M})$, and $2 \mu \mathrm{l}$ supernate of the boiled XL-1 solution. PCR was conducted in a GeneAmp 9700 (ABI). The amplification condition was one cycle of $94^{\circ} \mathrm{C}$ for $3 \mathrm{~min}$, then 30 cycles of $96^{\circ} \mathrm{C}$ for $20 \mathrm{~s}, 55^{\circ} \mathrm{C}$ for $30 \mathrm{~s}$ and $72^{\circ} \mathrm{C}$ for $10 \mathrm{~s}$, and finally, the temperature decreased to $4^{\circ} \mathrm{C}$ for ending the reaction and product storage.

Electrophoresis of the PCR products Five $\mu$ of the PCR products were loaded onto $1.5 \%$ agarose (TaKaRa) gel, electrophoresis at $75 \mathrm{~V}$ for $45 \mathrm{~min}$, with DNA marker DL2000 (TaKaRa) as a reference. The electrophoresis results were observed in a UVP mini-dark room and a photo was taken.

Experiments on transferring methods of DNA bands in the agarose gel In order to find a simple and rapid method that can consistently recover the DNA band in the agarose gel after electrophoresis of the first-PCR products, we tried 4 different transferring methods. For convenience of the comparison, we picked the white clones containing a 500 bp-length control fragment in the control group that was supplied by the kit for this study.

After the gel was checked under long wavelength ultraviolet light, one of the following methods was used to transfer the PCR product bands in the gel to an eppendorf tubes (EP tube) for a secondary PCR amplification.

1. Gel cutting. For every target band in the gel, under the long wavelength ultraviolet light, using a sterilized gauge 11 lancet that exactly cuts off the gel band containing the amplified PCR product, the isolated gel band was transferred to an EP tube containing $100 \mu \mathrm{l}$ UPW. It was then left at room temperature for more than $30 \mathrm{~min}$. It was followed by centrifugation at $12,000 \mathrm{rpm}$ for $10 \mathrm{~min}$. The supernatant was used as the template for the secondary PCR.

2. Sterilized pipette tips were cut off at the half side of the pinnacles. The trough-shaped tip was used to excavate the gel band for recovery of the DNA. The rest protocols of soaking and centrifugation were the same as 1 .

3. Sterilized filter papers were cut into $1 \mathrm{~cm}$ long triangle-shaped pieces, dried at $80^{\circ} \mathrm{C}$ for $1 \mathrm{~h}$. For transferring of the DNA in the gel, forceps were used to take a piece of the paper. The sharp end was inserted into the gel band and remained for a few seconds, then transferred into an EP tube containing $100 \mu \mathrm{l}$ UPW. The rest protocols of soaking and centrifugation were the same as 1 .

4. Sterilized wooden toothpicks were cut into pieces of $1 \mathrm{~cm}$ length. The rest protocols of transferring, soaking, and centrifugation protocols just the same as 3 .

The second PCR A $20 \mu \mathrm{l}$ PCR reaction solution contained $6 \mu \mathrm{l}$ UPW, $10 \mu \mathrm{l}$ premix, $1 \mu \mathrm{l}$ primer $\mathrm{S} 1(10 \mu \mathrm{M}), 1 \mu \mathrm{l}$ primer $\mathrm{S} 2$ $(10 \mu \mathrm{M})$, and $2 \mu \mathrm{l}$ supernatant of the soaking solution as the template. The temperature cycle program was exactly the same as the first PCR. For electrophoresis of the secondary PCR products, see step 6 .

DNA microarray probes preparation Lambda phage DNA fragments-transformed white colonies were picked. Each colony was inoculated to an EP tube containing $500 \mu \mathrm{LB}$ and $60 \mu \mathrm{g} / \mathrm{ml}$ Amp, then incubated. The first PCR was performed as in step 5, electrophoresis as step 6. The DNA bands were transferred using the method of wooden toothpick insertion. The secondary PCR was done in a $100 \mu \mathrm{l}$ reaction system containing $40 \mu \mathrm{l}$ of UPW, $50 \mu \mathrm{l}$ of $2 \times$ premix, $4 \mu \mathrm{l}$ of primer S1, $4 \mu \mathrm{l}$ of primer S2, and $2 \mu \mathrm{l}$ of the supernate of the soaked toothpick solution. The temperature program was pre-denaturation at $94^{\circ} \mathrm{C}$ for $5 \mathrm{~min}$, then 35 cycles of $94^{\circ} \mathrm{C}$ for $30 \mathrm{~s}, 55^{\circ} \mathrm{C}$ for $30 \mathrm{~s}$, and $72^{\circ} \mathrm{C}$ for $10 \mathrm{~s}$. The last cycle of $4^{\circ} \mathrm{C}$ was for stopping the reaction and storage of the PCR products. Four $\mu \mathrm{l}$ of the products was loaded onto $1.5 \%$ agarose gel for electrophoresis to exam the quality and quantity of the products.

If the DNA bands of the PCR products in the agarose gel appeared in a single band (located between $200 \mathrm{bp}$ to $1,000 \mathrm{bp}$ ), and the fluorescent yield of the DNA band was not less than that of the corresponding DNA marker band (the DNA marker contained $50 \mathrm{ng}$ of DNA in each band after electrophoresis, so the PCR products should contain the amplified probe, more than 1,000 ng in a $100 \mu \mathrm{l}$ system). The remaining $96 \mu \mathrm{l}$ of the products was subjected to further purification.

The remaining $96 \mu \mathrm{l} \mathrm{PCR}$ products were precipitated by adding $100 \mu \mathrm{l}$ isopropyl alcohol, stored at $-20^{\circ} \mathrm{C}$ for more than $2 \mathrm{~h}$, then centrifuged at $12,000 \mathrm{rpm}$ for $15 \mathrm{~min}$. After removing the supernate, the precipitate was washed by $200 \mu 170 \%$ ethanol and vacuum dried. Seven $\mu$ U UPW was added to resolve the precipitate, and $1 \mu \mathrm{l}$ of the solution was taken to determine the concentration. The samples with concentrations of not less than $500 \mathrm{ng} / \mu \mathrm{l}$ were selected as probes for the microarray printing. The remaining $6 \mu \mathrm{l}$ of the probe solution was transferred to a 384-well plate in a prearranged order. An additional $6 \mu \mathrm{l}$ of dimethyl sulfoxide (DMSO) was added into each well in the plate containing $6 \mu \mathrm{l}$ probes. The total volume of the probe sample was $12 \mu \mathrm{l}$ to form $50 \%$ DMSO as a spotting solution.

DNA microarray printing The GIN-PCR amplified probes were spotted onto a CMT-GAPS aminosilane-coated glass microscope slide (Corning) at $25^{\circ} \mathrm{C}$ and $60 \%$ relative humidity, using the ArrayIt ChipMaker $2^{\mathrm{TM}}$ microspotting pins (TeleChem International, Sunnyvale, USA) and Cartesian PixSys 5500 robot (Cartesian Technologies, Ann Arbor, USA). A microarray of $20 \times 33$ spots 
(containing 219 sample probes that were collected from the lambda phage DNA fragments-transformed white colonies and one blank containing 50\% DMSO) were printed. Each sample probe and the blank were printed 3 times. The 3 blanks are located at row 10 and columns 16,17, and 18, respectively. After printing, the slide was re-hydrated over a boiling water vapor for a few seconds, then snap dried at $80^{\circ} \mathrm{C}$ for $5 \mathrm{~min}$, and cross linked by ultraviolet irradiation in a UV-cross-linker (Bio-Rad, Hercules, USA) for a total energy of $125 \mathrm{~mJ}$. This was followed by baking the slide at $80^{\circ} \mathrm{C}$ for $2 \mathrm{~h}$, and finally stored it in a dark place at room temperature for later use.

\section{DNA microarray hybridization}

1. Sample labeling. One $\mu \mathrm{g}$ of lambda phage DNA was digested at $37^{\circ} \mathrm{C}$ by Sau3AI for $3 \mathrm{~h}$. Two ends of every Sau3AI digested fragment were linked to an adaptor that was prepared by annealing the 2 oligonucleotides containing the sequences of 5'GATCCACACCAGCCAAACCCA and 5'-GGTTTGGCTGGTGTG in a ligation reaction containing $1 \mu \mathrm{l}$ T4 DNA ligase (350 U/ $\mu \mathrm{l})$, $1 \mu \mathrm{l} 10 \times$ DNA ligation buffer, $1 \mu \mathrm{l}$ the adaptor $(50 \mu \mathrm{M}), 20 \mathrm{pmol}$ of lambda DNA fragments of Sau3AI digest, then added UPW to the total $10 \mu \mathrm{l}$. After $4 \mathrm{~h}$ of ligation at $16^{\circ} \mathrm{C}, 25 \mu \mathrm{l} 2 \times$ premix, $2 \mu \mathrm{l}$ Cy5 labeled-universal primer matched with the adaptor, and $13 \mu \mathrm{l}$ UPW were added to the $10 \mu$ ligation solution to a final volume of $50 \mu \mathrm{l}$. A labeling temperature program of pre-denaturing was started at $94^{\circ} \mathrm{C}$ for $3 \mathrm{~min}$, followed by 30 cycle of $96^{\circ} \mathrm{C}$ for $20 \mathrm{~s}$, $60^{\circ} \mathrm{C}$ for $30 \mathrm{~s}$, and $72^{\circ} \mathrm{C}$ for $100 \mathrm{~s}$. Finally, the reaction was stopped by cooling down to $4^{\circ} \mathrm{C}$. After this labeling reaction, all of the sample DNA fragments of hundreds of base pairs were labeled with fluorescent Cy5. The labeled-sample PCR products were further purified using the 3S PCR product purification kit V20 (Bocai Corporation, Shanghai, China). Five $\mu \mathrm{l}$ of the $30 \mu \mathrm{l}$-purified products was used to hybridize with the DNA microarray probes.

2. Pre-hybridization and Hybridization. The DNA microarray slide was put into the pre-hybridization solution containing $25 \%$ formamide, $5 \times \mathrm{SSC}, 0.1 \%$ sodium dodecyl sulphate (SDS), and $1 \%$ bovine serum albumin (BSA) at $42^{\circ} \mathrm{C}$ for $45 \mathrm{~min}$. It was then rinsed in Milli $\mathrm{Q}$ water 5 times, followed by isopropanol dehydration and air-drying.

Five $\mu$ of the Cy5 labeled samples was mixed with $1 \mu$ l Cot- 1 DNA $(20 \mu \mathrm{g} / \mu \mathrm{l}$, Life Technologies) and $6 \mu \mathrm{l} 2 \times$ hybridization buffer $(50 \%$ formamide, $10 \times \mathrm{SSC}, 0.2 \% \mathrm{SDS}$ ) that had been preheated to $42^{\circ} \mathrm{C}$, then heated to $95^{\circ} \mathrm{C}$ for $5 \mathrm{~min}$ and centrifuged at $14,000 \mathrm{rpm}$ for $2 \mathrm{~min}$. This mixture was completely pipetted onto the pre-hybridized lambda phage DNA microarray slide and covered with a glass coverslip that had been pretreated with SIGMACOTE $^{\circledast}$ (Sigma, St. Louis, USA) to keep the sample from evaporation. The slide was put into a sealed hybridization box; $10 \mu \mathrm{UPW}$ was added to every well at the two ends of the chamber, respectively. The sealed chamber containing the DNA microarray slide was placed in a $42^{\circ} \mathrm{C}$ water bath. After $16 \mathrm{~h}$ of incubation, the slide was taken out and washed by the following: (1) low-stringency washing buffer containing $1 \times \mathrm{SSC}$ and $0.2 \% \mathrm{SDS}$ at $42^{\circ} \mathrm{C}$ for $5 \mathrm{~min}$; (2) high-stringency washing buffer containing $0.1 \times \mathrm{SSC}$ and $0.2 \% \mathrm{SDS}$ at room temperature for $10 \mathrm{~min}$; (3) $0.1 \times \mathrm{SSC}$; (4) Milli Q water; (5) ethanol. Finally, the air-dried slide was scanned using the ScanArray ${ }^{\mathrm{R}}$ Lite MicroArray Analysis System (Packard Bioscience, Boston, USA).

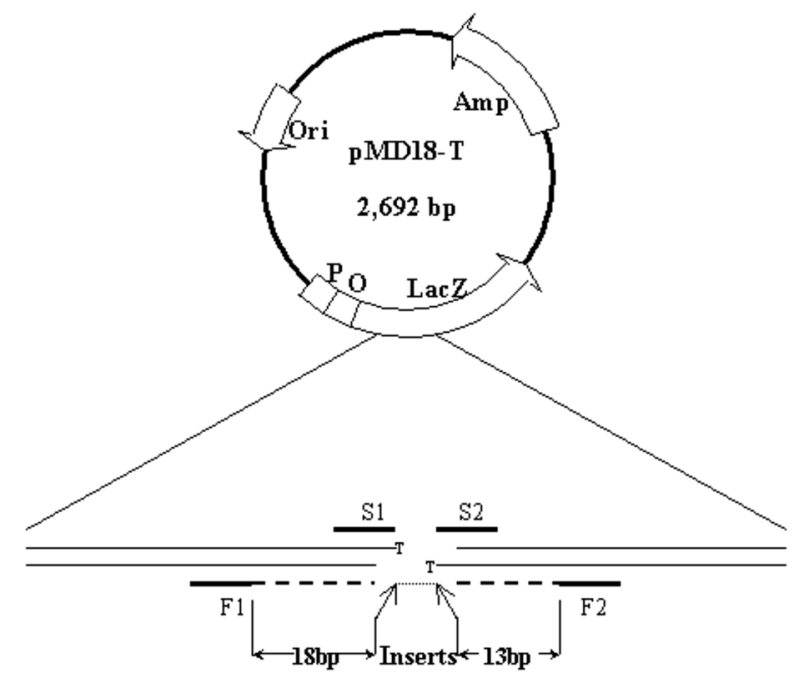

Fig. 1. A schematic representation of the pMD18-T vector and the location of the 2 pairs of nested primers designed from the pMD18-T vector for probe-preparation by GIN-PCR. The two primer sets flank the EcoR V site in the lacZ gene.

\section{Results}

Two pairs of nested primers were designed to amplify the DNA fragments that were inserted into the pMD18-T vector. $\mathrm{F} 1$ is located at $18 \mathrm{bp}$ upstream of the EcoR V site. F2 is located at 13 bp downstream the EcoR V site. S1 and S2 are exactly positioned at the $E c o \mathrm{R} \mathrm{V}$ site. An additional $\mathrm{T}$ is added to the 3' end of the 2 primers, $S 1$ and S2, for the purpose of matching the overhanging base A that comes from the Sau3AI-digested lambda DNA fragments (Fig. 1).

\section{First-PCR primers: F1: 5'>ACGAATTCGAGCTCGGTACC F2: 5'>AGTGCCAAGCTTGCATGCCT \\ Second-PCR primers: S1: 5'>CCGGGGATCCTCTAGAGATT S2: 5'>ATGCCTGCAGGTCGACGATT}

Four transfer methods were tried in this study. Positive control colonies, which harbored a 500 bp DNA fragment supplied by the ligation kit, were divided into 4 groups. Group I: 11-16; filter paper transfer. Group II: 21-27; lancet cut of the gel bands. Group III: 30-39; tip transfer. Group IV: 40-49; toothpick transfer (Fig. 2). Of the four transfer methods, the filter paper transfer and wooden toothpick technique showed better results than the lancet cut and tip excavation. All of the electrophoresis DNA bands in the filter paper transfer group and toothpick transfer group were clear, strong and steady, without smearing, while the lancet cut and tip excavation resulted in a poor recovery of the DNA band as the DNA bands in group II and group III are not consistent and strong smearing appeared, especially by the lancet cut method.

A total of 219 sample probes were collected from the lambda phage DNA fragments-transformed white colonies, including the probes collected from the 24 colonies (No. 289, 290, 291, 292, 293, 294, 296, 300, 301, 302, 303, 306, 308, 


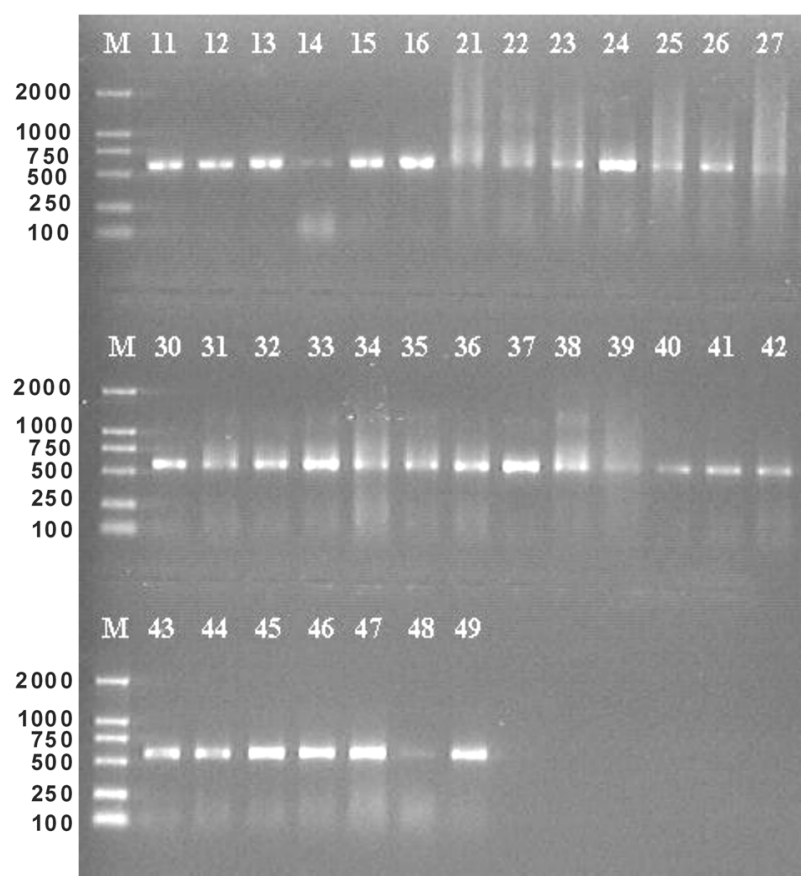

Fig. 2. Electrophoresis of the second-PCR products after DNA band recovery from agarose gel by 4 different methods. Lanes 11 through 16 resulted from the filter paper method, lanes 40 through 49 from wooden toothpick recovery, both with no smearing; lanes 21 through 27 from lancet cut, lanes 30 through 39 from tip transfer, both with smearing and recovery was not steady.

309, 310, 312, 313, 314, 316, 317, 318, 319, 321, 322, Figs. 3 and 4). From a comparative analysis of Figs 3 and 4, the 2 pairs of nested primers we designed from the pMD18 T-vector can effectively amplify the inserted DNA fragment. The first PCR amplifies the inserts with 2 flanking sequences of $38 \mathrm{bp}$ upstream and $33 \mathrm{bp}$ downstream, respectively, including the two 20 bp F1 and F2 primer pairs. The second PCR amplifies the inserts with 2 flanking $20 \mathrm{bp}$ primers sequences S1 and $\mathrm{S} 2$. As a result, the second PCR products are all $31 \mathrm{bp}$ shorter in length than the first PCR products.

The amount of DNA recovered by the toothpick technique from the DNA bands in the agarose gel after electrophoresis of the first PCR products is sufficient as the template for the second PCR amplification. The second PCR, amplifying sample No. 319, resulted in no products. Possibly this was a result of a man-made mistake, because of the inaccurate localization of the toothpick under the UV light.

For the microarray probe preparation, this DNA microarray that was fabricated from the lambda phage DNA fragments demonstrated that the GIN-PCR we employed in this study works well (Fig. 5). It is an effective technique to prepare a large number of probes for microarray construction in a short time. In theory, except for the 3 blank sites that are located at row 10 and columns 16, 17, and 18 with definitely no hybridization signals, all of the other spots in this microarray should produce hybridization signals; all because of the

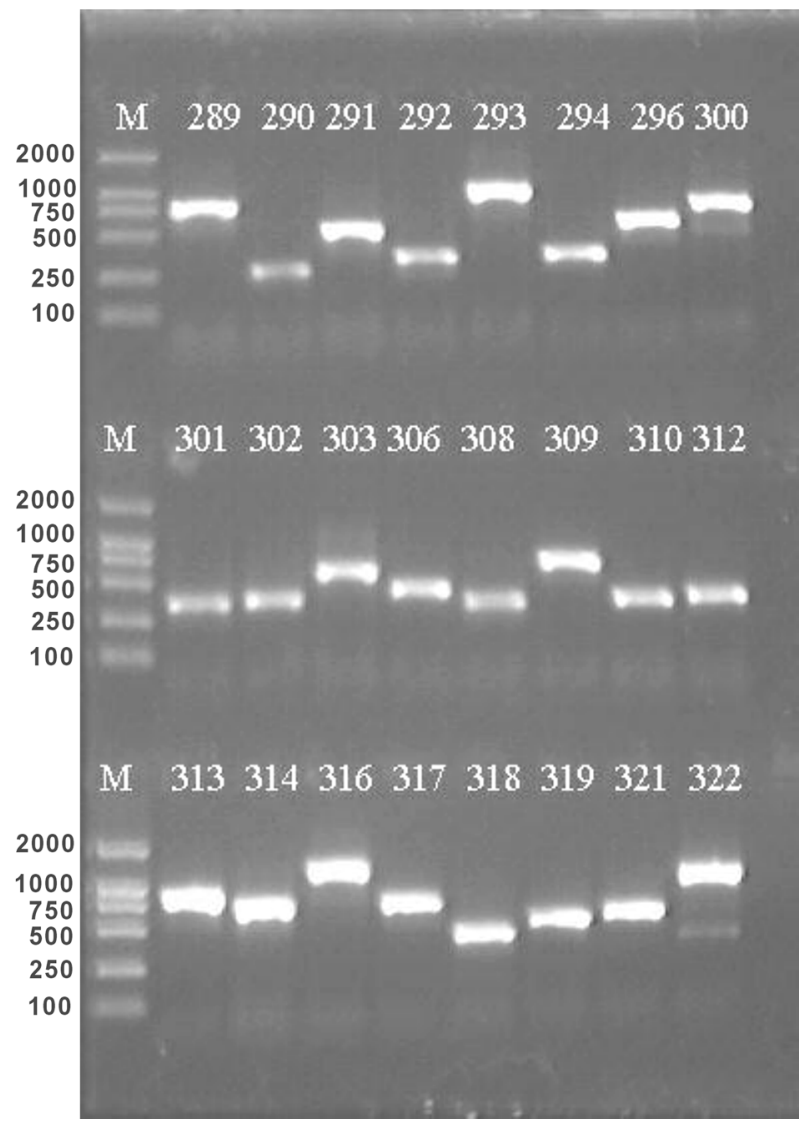

Fig. 3. Electrophoresis of the first PCR products from the white clones of lambda phage genomic fragments. PCR products $(5 \mu \mathrm{l})$ were loaded onto $1.5 \%$ agarose gel.

probes and labeled samples have the same origin. Actually, only $50.7 \%(111 / 219)$ of the probes produced evident hybridization signals, while $39.3 \%$ (86/219) of the probes produced faint signals, and $10.0 \%$ (22/219) no signals. As an estimate, these may be closely related to the hybridization conditions and other factors, such as GC percentage in the probes, or probe length, etc. They are beyond the scope of this study, therefore, our research will be extended in order to clarify the reason. Our results will be reported in a future paper.

\section{Discussion}

For the DNA microarray probe preparation (either cDNA probes or genomic DNA fragments probes), PCR amplification is still the primary method of choice, because of its rapidity, simplicity, and effectiveness (Ko et al., 2002; Liu et al., 2003). PCR amplification of complicated samples for probe preparation is especially predominant to other methods. However, conventional PCR is conducted with specific primers, considerations of costs arise from a synthesis of large numbers of PCR primers. Also, for ordinary PCR, we need to 


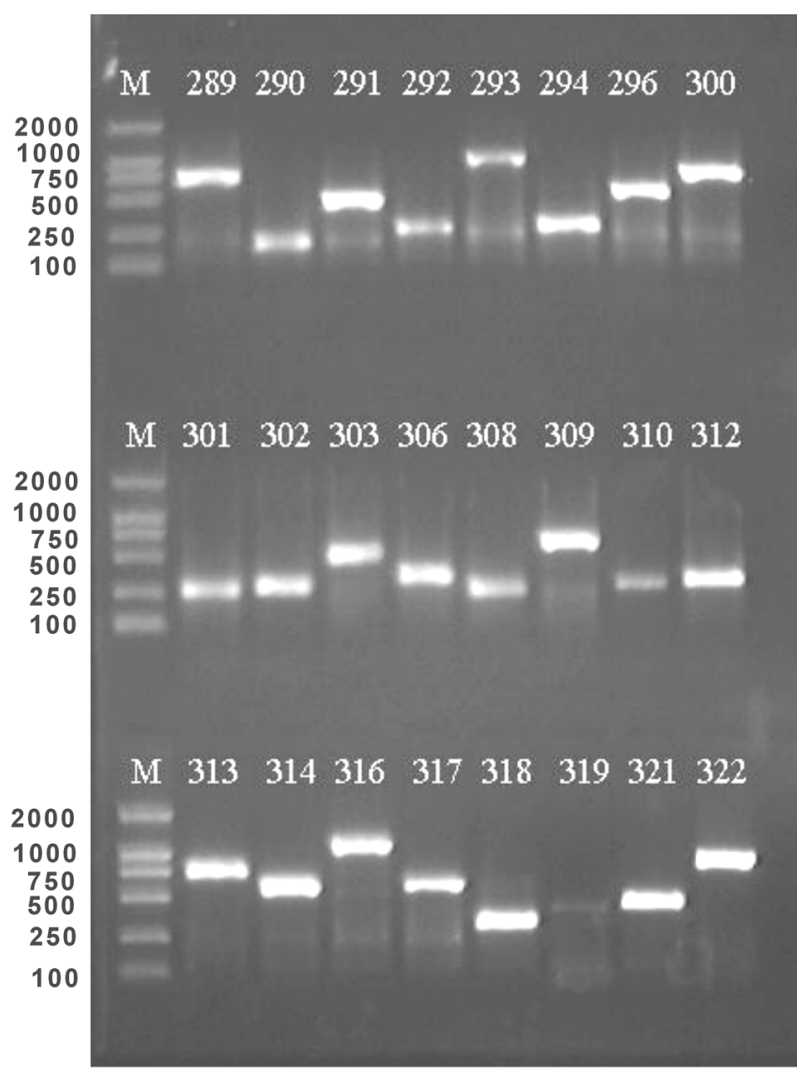

Fig. 4. Electrophoresis of second PCR products that were amplified from the first PCR products, which were transferred by a wooden toothpick. $4 \mu \mathrm{l}$ PCR products were loaded onto $1.5 \%$ agarose gel.

know the target sequence information. This may pose some difficulty in samples where the sequence information is limited.

There are reports of using conventional PCR to prepare DNA microarray probes (Hegde et al., 2000). The combination of clone identification and probe production in a $50 \mu \mathrm{l}$ PCR system inevitably resulted in a low success rate for probe collections. One of the most significant difficulties of preparing the DNA microarray probes was the mass scale of the probes, so the procedure may be labor intensive and less cost efficient. We used this double PCR in order to simplify the procedure of the probe preparation with the following advantages. Firstly, with $20 \mu \mathrm{l}$ first PCR, we can further identify the colonies that harbor the plasmids that were inserted with the foreign probe DNA fragments on the base of the Amp and blue/white colony screen. The first PCR amplifies with a pair of primers that are specific to the pMD18-T vectors, so that only the colonies that have been successfully transformed with the $\mathrm{T}$ vectors are amplified. Then, only the colonies harboring the inserted foreign DNA fragments are amplified to produce the PCR products. Using this first PCR mechanism, we can rule out a some of the colonies that cannot be used for microarray probe preparation. They are as follows: the colonies that produce 2 or more

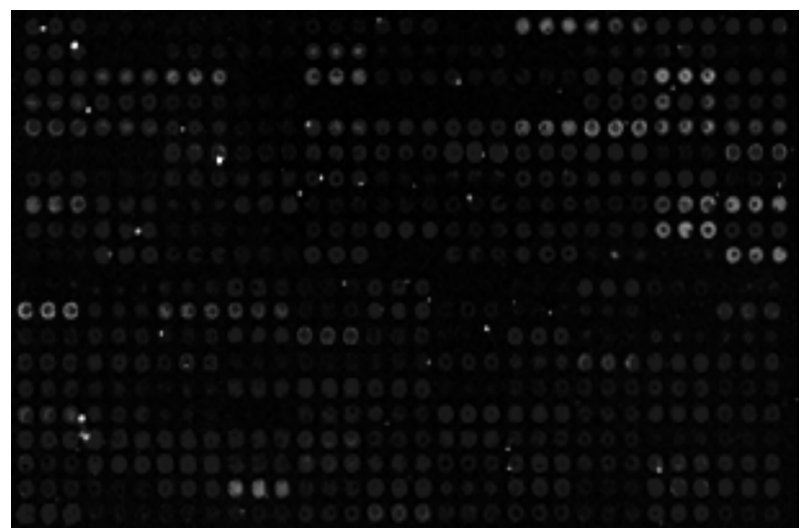

Fig. 5. A DNA microarray constructed using the probes that were prepared by GIN-PCR.

products with 2 or more electrophoresis bands; the colonies with too short (less than $200 \mathrm{bp}$ ) or too long (more than $1,000 \mathrm{bp}$ ) PCR products; or the colonies that produce only very weak PCR products. As a result, a large number of invalid PCR amplifications for probe collection are avoided; also cost and time are saved.

We used the second PCR of the $100 \mu \mathrm{l}$ system to produce probes. On the basis of the first PCR, a second PCR of the $100 \mu 1$ reaction system was performed using the first PCR products as the template after agarose gel electrophoresis isolation and purification. In this way, the products of the second PCR were purified better and with a much higher productivity and rate of success. In our experiments, more than $90 \%$ of the second PCR products were suitable for direct microarray printing as probes.

There are a number of conventional methods of DNA recovery from agarose gel electrophoresis (Sambrook et al., 1989). These include electrophoresis onto a DEAE-cellulose membrane, electroelution into dialysis bags, low-meltingtemperature agarose gels, etc. However, they are inconvenient when working with a large number of samples, as in case of the microarray probe collection. Our approach in this study was both cost-effective and less labor-intensive. Of the 4 methods of DNA bands transfer that we tested, the filter paper and wooden toothpick transfers both worked well. Lancet cut and tips excavation produced unclear bands with smear or ambiguous bands. We propose that these might result from the interference of the large numbers of agarose gel that were carried over with the transferred DNA of these two methods. Regarding the procedure, the filter paper method is not as convenient as the toothpick method, because it is more laborious to prepare the filter papers pieces for transferring. Also, it is difficult to insert it into the DNA bands in the gel because of its plasticity.

In this study, we used the restriction display (RD) technique to label the samples with the fluorescent Cy5-labeled universal primer (Zhang et al., 2002). By RD amplification of the enzyme-digested samples, the sample fragments can be 
significantly labeled with fluorescent signals and can produce a much stronger hybridization than the conventional labeling methods.

In conclusion, we developed a more cost-effective and less labor-intensive method for DNA microarray probe preparation by GIN-PCR. In other words, the first PCR products are isolated by agarose gel electrophoresis, and then transferred by toothpick insertion, which recovers the first PCR DNA bands in the agarose gel as the templates of the second PCR. Then a second round of nested PCR easily produces a large number of relevant DNA fragments that can then be collected and used as probes in DNA microarray preparation.

Acknowledgments The authors wish to thank Dr. Zhang Bao and Shi Rong for their critical technical assistance.

\section{References}

Albert, T. J., Norton, J., Ott, M., Richmond, T., Nuwaysir, K., Nuwaysir, E. F., Stengele, K. P. and Green, R. D. (2003) Light-

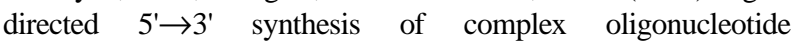
microarrays. Nucleic Acids Res. 31, 35.

Dziejman, M., Balon, E., Boyd, D., Fraser, C. M., Heidelberg, J. F. and Mekalanos, J. J. (2002) Comparative genomic analysis of Vibrio cholerae: Genes that correlate with cholera endemic and pandemic disease. Proc. Natl. Acad. Sci. USA 99, 15561561.
Hegde, P., Qi, R., Abernathy, K., Gay, C., Dharap, S., Gaspard, R., Hughes, J. E., Snesrud, E., Lee, N. and Quackenbush, J. (2000) A concise guide to cdna microarray analysis. BioTechniques. 29, 548-562.

Ko, J., Na, D. S., Lee, Y. H., Shin, S. Y., Kim, J. H., Hwang, B. G., Min, B. and Park, D. S. (2002) cDNA microarray analysis of the differential gene expression in the neuropathic pain and electro acupuncture treatment models. J. Biochem. Mol. Biol. 35, 420-427.

Liu, C. H., Ma, W. L., Shi, R., Ou, Y. Q., Zhang, B. and Zheng, W. L. (2003) Possibility of using DNA chip technology for diagnosis of human papillomavirus. J. Biochem. Mol. Biol. 36, 349-353.

Sambrook, J., Fritsch, E. F. and Maniatis, T. (1989) Molecular cloning, A Laboratory Manual, 2nd ed., Cold Spring Harbor Laboratory Press, New York, USA.

Schofield, D. and Triche, T. J. (2002) cDNA microarray analysis of global gene expression in sarcomas. Curr. Opin. Oncol. 14, 406-411.

Smith, L. and Greenfield, A. (2003) DNA microarrays and development. Hum. Mol. Genet. 12, 1-8.

Wang, H. Y., Malek, R. L., Kwitek, A. E., Greene, A. S., Luu, T. V., Behbahani, B., Frank, B., Quackenbush, J. and Lee. N. H. (2003) Assessing unmodified 70-mer oligonucleotide probe performance on glass-slide microarrays. Genome Biol. 4, 5.

Zhang, B., Ma, W. L., Hu, Z. Y., Rong, S., Shi, Y. B. and Zheng, W. L. (2002) A method for evaluation of the quality of DNA microarray spots. J. Biochem. Mol. Biol. 35, 532-535. 